\title{
REGIONAL SCIENTISTS AND REGIONAL IDENTITY \#
}

\author{
JAMES M. STEPP*
}

\section{Introduction}

I would like to begin my remarks by paying tribute to that unknown (at least to me) person who coined the term "regionalism," and a family of related terms, to refer to studies, analyses, policies, programs and problems relating to sub-national geographical areas and the social, economic and political entities, attitudes and relationships associated therewith. "Regionalism" is a much more attractive label than "sectionalism," the term that historians and others applied to the conflicting geographical interests and attitudes, and to the resulting public policy conflicts and disputes, throughout all of the 19th century and the first half of the 20th century. The label may not sell the product, but it certainly has a major influence on the extent to which people take time to test it.

Actually, though, as much as I admire the term "regional science," and despite the enthusiasm with which I embraced it to designate much of the work I have done during the past 30-odd years, I do not intend to devote any time to trying to find out who used it first. The older I get and the more I read, the more convinced I become that very few ideas and concepts can properly be attributed to any one person. For example, ever since the 1930's when I read a translation of his concentric zone theory of land use around a market center, I had until very recently given von Thunen full credit for originating both the idea and the model he presented. I was, therefore, much surprised a few months ago to read the following in a book that was published 60-odd years before von Thunen's Der Isolierte Staat:
... Thus we commonly find agriculture disposed in the following man- ner. In the center stands the city, surrounded by kitchen-gardens; be- yond these lies a belt of fine luxuriant pasture or hay-fields; stretch be- yond this, and you find the beginning of ... plowing and sowing; beyond this lie grazing farms for the fattening of cattle; and last of all come the mountainous or ill improved grounds, where animals are bred. This seems the natural distribution, and such I have found it almost every where es- tablished, when particular circumstances do not invert the order. ${ }^{1}$

The author then went on to explain the land-use pattern in terms of transport costs for people and commodities, and he cited and rationalized some exceptions

*Clemson University, Clemson, South Carolina.

\#Presidential Address, Annual Conference of the Southern Regional Science Association, Atlanta, Georgia, April 3-4, 1975. 
to the rule in much the same way that such is done in land economics textbooks currently in use.

The writer to whom I am referring is Sir James Steuart, a member of the Scottish nobility, who lived from 1713 to 1780 , and who seemed to have a talent for antagonizing influential people and backing losers in the bitter political struggles of his time. A very active Scottish nationalist, he found it expedient after the battle of Culloden, where the English in 1746 thoroughly and apparently finally defeated the Scots, to spend the next 17 years on the continent of Europe, where he studied political economy and traveled extensively.

My reference to the late and largely unlamented Sir James Steuart is intended to serve two purposes. The first is to justify my reluctance to impute the origin of an idea or concept to any one person, or to devote much of my time to tracing the genealogy of ideas and concepts. I am much more concerned with their validity and their usefulness. You will note that I did not give Sir James Steuart credit for originating the concentric zone theory; I simply pointed out that he discussed it several decades before the writer who has been given such credit by many people.

My second purpose is to use Steuart's literary obscurity to focus attention upon the fact that a regional identity is not an unmixed blessing. He had other liabilities, including his style of writing and his personality, but Sir James Steuart's close association with the losers in the English-Scottish conflict of the mid-18th century undoubtedly discouraged the examination and acceptance of his ideas by public officials, moulders of public opinion, and members of the academic establishment such as Adam Smith.

\section{Meaning and Importance of Regional Identity}

I assume that everyone here has his or her own ideas of how to define "region," "regional science," and "regional scientist," and I also assume that the definitions have enough in common to make it unnecessary (but enough differences to make it unwise) for me to give a series of definitions. I refer those who want such to the first chapter of Walter Isard's new book, where he gives the reader a choice among 13 definitions of "regional science."”

However, I feel that I should indicate what I mean by the term "regional identity." I am using the term in somewhat the same way that I understand sociologists, psychologists and ethologists refer to the feelings of empathy, sympathy and attachment which individuals have for groups or places, and which cause the individuals to take a special interest in phenomena which affect or threaten what is perceived to be the welfare of such groups or those living in such places. It is a mixture of group identity and territoriality, with emphasis on the latter, and it involves acceptance of that identity by others. I realize that it is possible for anyone to adopt a particular regional point of view or accounting stance for purposes of analysis, and that consultants to state and local governments do this constantly in the same way that lawyers seek (and are obligated) to do the best they can for their clients. However, I would call that a regional accounting stance rather than a regional identity. 
One of the first things a student of economic and social policy learns very quickly is that every attempted solution to or means of dealing with a problem, no matter how much the overall benefits may exceed the overall costs, makes some groups worse off either absolutely or in their comparative competitive position, or both. It is in the economic interest of the residents of any region or state to have their problems solved at the expense of others, and to have national problems defined and dealt with in ways that maximize the beneficial effects and minimize the adverse effects upon that group or region. This readily understandable phenomenon is a matter of uneasy concern in regions whose residents consider themselves to be national or even regional minorities whose interests and social values may be overlooked, contravened or impaired by an unconcerned or unsympathetic majority living in other regions. Examples which come readily to mind are the racial and ethnic communities in large cities; most of the South, especially the rural South, and sparsely-populated areas of the West.

There is, therefore, a strong interest at the municipal, county, state and regional levels in what economists and others employing a national perspective often dismiss somewhat perfunctorily as pecuniary or distributive aspects rather than technological or efficiency aspects of problems, proposals and actions. But to many, and perhaps I should say most, people the most important question about any proposal for government action or control is, "How will it affect Keowee County?" "How will it affect the inner city?" "How will it affect Texas?" "How will it affect the Northeast?"

These are not trivial questions to the people who ask them, and a very large percentage of public officials in the United States, plus members of countless voluntary community organizations, ask such questions or, in some cases, wish later that they had done so. Take, for example, the reaction of United States Congressmen and state governors to the petroleum tariff and related measures proposed by President Ford last February. The Governor of Texas (in a television interview) opposed it on the grounds that it would injure the economy of Texas; Senator Buckley, of New York, gave it a very tentative endorsement contingent upon further analysis revealing that the Northeast would not bear an unequal share of the higher costs of imported oil, ${ }^{3}$ and the Governor of at least one Southeastern state reacted by asking his advisers whether it was in the interest of his state to endorse or to oppose the proposal.

People and groups who ask such questions, or wish they had done so in the past, constitute the major actual and potential markets for the services of regional scientists who have a regional identity as I am using the term. They can serve as consultants and advisers to state and local governments, and to special regional agencies such as metropolitan districts and multi-county development commissions and councils which exercise government authority or influence with respect to certain programs and activities. This is a service to the "power structure" in its decisions regarding what ought to be done and how to do it. Although we have a long way to go in this direction, I am encouraged by the extent to which such agencies, especially state agencies and officials, are using social scientists as consultants, advisers and, to a lesser extent, as staff members. 
There are many meaningful bases for delineating sub-groups of regional scientists other than that of regional identity and activities related thereto. Some are economists; others are sociologists, geographers, demographers, or political scientists. Some are primarily theorists, concerned largely with the logical consistency of the propositions and models of regional science; others are quantifiers who seek and test empirical proxies for data needed to apply theories to realworld problems, and still others are concerned primarily with finding the right theoretical and empirical tools to deal adequately with specific problems. My discussion relates to a large and growing sub-group in the last-named category.

\section{Advantages and Disadvantages of Regional Identity}

If first-hand experience is worth much for this purpose, I am in an excellent position to give a "worm's eye view" of both the advantages and the disadvantages of having a regional identity over a fairly long period of time. My identity as a Southern Appalachian was a major factor in my being admitted to Berea College in the 1930's, and my identity as a rural Southerner was instrumental in my being chosen in 1940 to conduct an extensive study of rural industrial development under a grant from the General Education Board to Clemson University. I got "plugged into the system" fairly early in my professional career, and very few years have passed since 1941 without me being involved with some regional government agency in some aspect of economic development or of regulations pertaining thereto. Even if I had wished it otherwise, there was no way for me to avoid having a regional identity in the eyes of those with whom I worked.

Needless to say, there are both advantages and disadvantages to a problemoriented social scientist staying in one state (which is the principal sub-national decision-making political entity in this country) for a long enough period of time to become identified with that state in the view of officials and other influential persons as well as in his or her own mind. I want to comment on some of the more important of these advantages and disadvantages as some of my colleagues and I have experienced them at Clemson University. I assume that much the same conditions exist for faculty members at other service-oriented academic institutions, and also for professional staff members of federal, state and local government agencies. I hope these comments will be useful to young regional scientists as they choose a mix of mobility and stability in their professional careers.

My discussion of the advantages of a regional identity is divided into two parts; advantages to the regional scientist, and advantages to the regional residents, agencies and groups constituting the regional scientist's clientele. My discussion of disadvantages is restricted to the viewpoint of the regional scientist; I leave it to some public official at some future date to expound upon the disadvantages of having activist regional scientists offering unsolicited advice on controversial issues and providing consulting service to their political opponents and other dissident groups.

There are at least three advantages to a social scientist in acquiring and maintaining the kind of regional identity I have described. First, contact and in- 
teraction with regional agencies, groups and public officials make it possible to understand their problems sufficiently to interpret them in terms of relevant research and relevant policy issues, and to anticipate future problems while there is time to subject them to systematic research before they become so urgent as to stimulate hasty and unwise political action. There is nothing that makes a researcher who is concerned with real-world problems feel better than to have answers already developed when important questions are finally recognized and raised by public officials and the general public, and to have enough rapport with decision-makers for them to pay attention to one's findings. Helping state or other regional officials to ask the right question is useful even when the answer is not known.

Secondly, the regional scientist having a regional identity will, or should, have enough knowledge about enough aspects of that region's resources, people and institutions to provide a commonsense basis for evaluating the operational validity and usefulness of analytical models that are developed by scientists with different regional perspectives or different experiences and associations, and for devising appropriate modifications. Valuation and other criteria and coefficients that are appropriate for one region are not necessarily appropriate for another. Needless to say, before one can modify a model to meet the conditions existing in a particular region it is necessary to have a thorough understanding not only of the region but also of the model and the theory upon which it is based.

The third advantage to a social scientist of having a regional association or identity for a period of several years, and of taking an active interest in the development and/or problems of a particular region, is or should be enhancement of his or her capacity for recognition and specification of problem areas needing to be studied, and for the development of reasonable hypotheses related thereto. After analysis of a problem has revealed its basic nature, the hypotheses actually tested may bear very little superficial resemblance to the original problem. Students of the history of science will recall that Galileo began with a problem of inaccuracy and unpredictability of a military weapon (cannon) but ended up using an inclined plane to test some hypotheses about the behavior of falling bodies. ${ }^{*}$ Hopefully, knowledge of regional social structures and relationships, in addition to knowledge of relevant theory, should aid social scientists in somewhat the same way that knowledge of both cannons and physics helped Galileo transform a realworld problem into a relevant research problem.

I can think of four advantages to the officials and residents of a region (such as a municipality, county, state or multi-state area) in having well-informed regional scientists who identify with and are identified with that region. First, such scientists constitute a readily-available source of data, analytical competence and knowledgeable advice in questions requiring quick decisions. The most recent example is the energy allocation problem, but there is a continuing stream of federal administrative and legislative proposals which require quick action by states in either endorsing or opposing them.

Secondly, resident regional scientists who have rapport with public officials and/or special-interest groups can serve usefully as a channel for putting such of- 
ficials or groups in touch with outside (including federal) agencies and consultants having special qualifications and capabilities for dealing with specific kinds of problems. This, of course, requires that regionally-identified regional scientists be acquainted both personally and professionally with their colleagues who do not have any particular regional identity or who live in and are identified with other regions. If this statement is construed to be a "plug" for active membership in a professional regional science association, and especially the Southern Regional Science Association, you have not misunderstood me!

The third advantage to the clientele of having available regional scientists with special knowledge about and understanding of a particular region is the assistance they can give outside consultants and agencies when economic and/or political considerations cause regional officials and groups to seek the services of such agencies in dealing with some regional problem, program or policy. Here again the need for interregional and interpersonal professional contact and acquaintance is evident.

A fourth advantage to those who consider themselves to be permanent residents of a region, or whose economic interests are likely to be affected importantly by changes in conditions of interregional competition, of having regional scientists who identify with that region is their potential for service as an "early warning system" against national administrative policies or legislative proposals that are or threaten to be detrimental to a region's development, growth, environmental quality or interregional competitive position in some sector of the economy. Social scientists who understand interregional economic and social relationships and causal sequences are much more likely than laymen to discern the potential impact distant phenomena may have upon a region. One example is the interest that a number of northern urban economists and demographers have taken in the migration of rural southerners. Another is the interest of some agricultural economists in the humid South regarding proposals for large-scale transfers of water to the arid Southwest for irrigation purposes. ${ }^{5}$ Still another is the concern of some regional economists over the effects of pollution control regulations and action programs on interregional competition and regional development. ${ }^{6}$

\section{Disadvantages}

The disadvantages of a regional scientist having a regional identity are in direct proportion to how much that identity is recognized by public officials and leaders of voluntary groups who constitute the clientele of the scientist, how much interaction there is between the scientist and this clientele, and how much of this interaction is initiated by the clientele. Interacting and maintaining rapport with public officials and others concerned with regional policies and programs is a timeconsuming activity which is quite likely to occur at the convenience of the clientele rather than the convenience of the professional person. Work by academic personnel with or for a state legislative committee or executive department must often meet legislative deadlines with little regard for academic schedules and commitments. This hampers or precludes the scholarly contemplation and thorough analysis for which social scientists usually feel a need when confronted with tasks 
requiring research and/or evaluations of alternatives. Quick answers to tough questions must often be provided very largely on the basis of what one already knows or data and analytical models that are readily available, and methodologies or models may have to be improvised or modified on an ad hoc basis. Professional advisers to national groups and federal agencies no doubt encounter somewhat similar problems, but data, funds and professionally-qualified help are much more plentiful at the national level than at the state, county or regional level.

A second possible disadvantage to a regional scientist in being identified with a particular state or region is the old axiom that a prophet is not without honor save in his own country. Laymen who get to know us fairly well may have a better understanding of our personal peculiarities and shortcomings than of our professional knowledge and capabilities, and the "outside expert" has a certain glamour that a "local yokel" cannot match. Many of you, no doubt, have had the unflattering experience of having some of your data and ideas "sanitized" and made acceptable by being processed through an outside consulting agency before being passed along to an agency or group in your state or region. The fact that such is often justifiable on pragmatic grounds is covered by my next point.

Thirdly, it is difficult for a problem-oriented regional scientist who identifies with and is identified with a particular state or region for an extended period of time to avoid becoming also identified with certain agencies and officials in the bureaucracy. This would be no serious inconvenience if all government agencies, bureaus and officials worked together unselfishly and harmoniously for the public good. However, in the "real world" of the public sector such a happy situation is encountered about as often as perfect competition is encountered in the "real world" of the private sector. There is danger, therefore, that if one has a research and advisory relationship with state, regional or local government agencies over an appreciable period of time, even on an intermittent and informal basis, in any subject area or problem area, he or she may get caught in the middle of bureaucratic jealousies and power struggles. When a regional scientist operates in such an environment he or she should be constantly aware of the fact that the nature of problems, the relative value of alternatives, and the political power structure change over time. A recommendation of a particular method of dealing with a problem or managing a natural resource can very easily be construed as supporting or opposing particular bureaus or agencies, and disclaimers of such may not be sufficient to preserve credibility as an objective and impartial analyst.

Another problem encountered by many policy-oriented scientists with a strong regional identity is the difficulty of being an impartial, objective analyst of problems about which one cares in a personal way, and of programs operated by officials whom one knows well enough to have personal opinions about their strengths, weaknesses and personalities. Special care and self-discipline are required, and there are many situations where the best use of the expertise of a knowledgeable regional scientist with a particular regional identity requires collaboration with outside consultants who can contribute to both the fact and the image of objectivity. A policy-related professional report, like the man in the 
television commercial for a certain brand of soap, must not only be "clean," it must smell "clean!" The extent to which this solution may itself create problems varies inversely with the thickness of the professional skins of the regional scientists involved.

\section{Concluding Remarks}

I have discussed regional identity from the perspective of regional scientists living and working in the region with which they identify. In this connection I think of a remark one of my Clemson friends made about a local organization of which he was a member. "You don't have to be crazy to be a member," he said, "But it helps!" You don't have to live in a region to identify with it and its people, but the various advantages and disadvantages I have discussed are most applicable when such is the case.

In a mobile society such as ours, many people are no doubt unaware of having a particular regional identity for some time after it has sneaked up on them. Few people are as positive about having acquired a new regional identity as a recently-arrived South Carolinian who began a speech a few years ago as follows: "One of my great regrets is that I had the misfortune not to be born in my native state of South Carolina." More typical, I think, is a transplanted North Carolinian who recently confessed in his newspaper column that he did not realize he had acquired a South Carolina identity until he found himself, to his surprise, cheering for South Carolina basketball teams playing against North Carolina opponents, including his alma mater, in some recent intercollegiate tournaments.

Like good habits and bad habits, a regional identity can be acquired imperceptibly and unconsciously. For a regional scientist, the disadvantages of having a particular regional identity will be minimized, and the advantages will be maximized, if he or she recognizes and acknowledges such an identity and takes care to protect and preserve his or her professional impartiality and objectivity.

\section{FOOTNOTES}

${ }_{1}^{1}$ Steuart, Sir James, An Inquiry Into the Principles of Political O economy (first published in 1767). Edited by Andrew S. Skinner, and published in 1966 for The Scottish Economic Society by Oliver and Boyd, Ltd., Edinburgh and London, pp. 134-135.

"Isard, Walter, Introduction to Regional Science. Prentice-Hall, Inc., Englewood Cliffs, N. J., 1975, p. 5.

:Reported in U.S. News and World Report, Feb. 10, 1975, p. 23.

See Northrop, F. S. C., The Logic of the Sciences and the Humanities. The Macmillan Co., New York, 1947, pp. 22-26.

"See, for example, Tolley, George S., "Reclamation's Influence on the Rest of Agriculture." Land Economics, May 1959, Vol. 35, No. 2, pp. 176-180.

6E.g., Hite, James C., et al. The Economics of Environmental Quality, Chapter 4. Domestic Affairs Study 5, American Enterprise Institute for Public Policy Research, Washington, D. C., 1972. 